\title{
Molecular Diversity among the Isolates of Xanthomonas axonopodis pv. citri Causing Bacterial Canker in Citrus
}

\author{
Rutuja R. Kharde ${ }^{1}$, Shivaji A. Lavale ${ }^{2}$ and Bhausaheb Baban Ghorpade ${ }^{1 *}$ \\ ${ }^{1}$ College of Agricultural Biotechnology, Loni, Ahmednagar, MS, India \\ ${ }^{2}$ College of Agricultural Biotechnology, Takli-Kazi, Ahmednagar, MS, India \\ *Corresponding author
}

\section{A B S T R A C T}

\section{Keywords \\ Molecular diversity, RAPD, ISSR, Cluster analysis, Xanthomonas axonopodis pv. citri \\ Article Info \\ Accepted: \\ 12 July 2018 \\ Available Online: \\ 10 August 2018}

Genetic variability study of five isolates of Xanthomonas axonopodis pv. citri was carried out using molecular markers. The isolates were collected from five places in Maharashtra state, India. Morphological and Biochemical tests viz. gram's reaction, starch hydrolysis, indole production, catalase test, $\mathrm{KOH}$ test, Gelatin liquefaction and Acid production test were carried out to identify and confirm the purity of the culture. The genetic variability was studied by using 14 RAPD and 8 ISSR primers out of which 7 RAPD primers produced 47 scorable bands and 2 ISSR primers produced 13 scorable bands. The similarity coefficient value ranged from 0.13 to 0.40 for RAPD and from 0.00 to 1.00 for ISSR primers across five isolates indicating high degree of genetic variation.

\section{Introduction}

Citrus as a fruit crop is having a great importance as it is delectable, juicy with great nutritional significance and therapeutic qualities as well (Chaudhry et al., 1992; Khan et al., 1992).

It is grown on an area about 9.08 million hectare with the production of around 139.80 million tones. In India it is grown on 1.02 million hectare area with the production of around11.15 million tones (FAOSTAT, 2017). Citrus canker disease caused by Xanthomonas axonopodis $p v$. citriis an important threat to citrus crops produced all over the world. Symptoms of the disease include necrotic lesions on leaves, twigs and fruits which subsequently can cause leaf abscission, twig die-back and premature fruit drop (Gotwald et al., 1993; Schoulties et al., 1987).

Controlling the disease is a difficult task as the pathogen has different pathovar sand strains within the pathovar across the locations which differ genetically. Genetic diversity determination is done on basis of morphological, biochemical and molecular types of information. Molecular markers show genetic differences on a more detailed level without interferences from environmental factors, and where they involve techniques that provide fast results detailing genetic diversity. Several molecular techniques have 
been used to study the population structure of different plant pathogens, including RAPD, Rep and Eric-PCR, RFLP, plasmid profile analysis, PCR amplification, SDS-PAGE, sequencing of the 16S rDNA, and pulsed field gel electrophoresis (Pooler et al., 1996; Hauben et al., 1997; Rademaker et al., 2000; Kolliker et al., 2006; Simoes et al., 2007).

The objective of this study was to study the genetic diversity of $X$. axonopodis pv. citri strains collected from different geographic regions of Maharashtra state, India by using RAPD and ISSR markers.

\section{Materials and Methods}

\section{Collection of disease samples}

The leaf samples showing typical symptoms of citrus canker were collected from five different locations (Table 1) during OctoberNovember, 2015.

\section{Isolation of X.axonopodis pv. citri}

Nutrient Agar (NA) medium composed of $0.3 \%$ Beef extract, $0.2 \%$ Yeast extract, $0.5 \%$ Peptone, $0.5 \%$ Sodium chloride and $1.5 \%$ Agar agar was used for isolation of X.axonopodis pv. citri. The selected diseased leaves were washed thoroughly with tap water and surface sterilized with $0.1 \%$ sodium hypochlorite solution for 5 minutes and washed again with sterile distilled water to remove the traces of sodium hypochlorite. Leaves were allowed to dry on sterilized tissue paper. The infected portion of leaf along with healthy part was excised carefully on sterilized slide using scalpel blade. A drop of water was added on the tissue to macerate it gently using glass rod. Bacterial cells were allowed to ooze out until the water became slightly turbid. A small volume of exudates was collected and streaked on NA medium and incubated at 25 to $28^{\circ} \mathrm{C}$ temperature.

\section{Pathogenicity test}

Healthy leaves were washed with water, sterilized with $70 \%$ ethanol for 1 minute and rinsed twice with sterile distilled water. Three leaves were placed on four layers of sterile blotting paper towel in covered Petri plates. These were inoculated in vitro with pin prick method (Di et al., 1991) in which sterile pins dipped in inoculum were used to prick the leaves on sides and in the center. The pathogen was re-isolated from the infected leaf samples after it showed the typical symptoms of canker to ensure the infection by $X$. axonopodis $p v$. citri. The identification of the pathogens was determined by conducting studies on morphological and biochemical tests viz. gram's reaction, starch hydrolysis, in dole production, catalase test, $\mathrm{KOH}$ test, Gelatin liquefaction and Acid production test.

\section{DNA extraction from $X$.axonopodis $p v$. citri}

Total genomic DNA of $X$. axonopodis pv. citri strains was extracted by using the protocol described by Cooksey and Graham (1989) and Egel et al., (1991), with few modifications. Pure culture was multiplied in nutrient broth in $100 \mathrm{ml}$ flask at $28{ }^{\circ} \mathrm{C}$ for 72 hours with vigorous shaking at a speed of $120 \mathrm{rpm}$. About $1.5 \mathrm{ml}$ aliquots of broth culture were taken in $2.0 \mathrm{ml}$ of micro-centrifuge tube and spun at $13000 \mathrm{rpm}$ for 5 minutes. The supernatant was discarded and $200 \mu 1$ of lysis buffer was added to the tubes containing pellet and was mixed well. $66 \mu \mathrm{l}$ of $5 \mathrm{M} \mathrm{NaCl}$ was added and contents were centrifuged at $13000 \mathrm{rpm}$ for 10 minutes. Supernatant $(250 \mu 1)$ obtained was transferred to a new tube, to which $1 \mu$ RNase $(20 \mathrm{mg} / \mathrm{ml})$ was added, mixed well and incubated at $37^{\circ} \mathrm{C}$ for 30 minutes. An equal volume of chloroform isoamyl alcohol was added, mixed gently by inverting the tubes and centrifuged at $13000 \mathrm{rpm}$ for 6 minutes. The upper aqueous phase was transferred to a clean tube and $1 \mathrm{ml}$ of $95 \%$ ethanol was added. 
The tubes were then kept in deep freezer at $20{ }^{\circ} \mathrm{C}$ for overnight. After incubation tubes were spun at $13000 \mathrm{rpm}$ for 6 minutes. Ethanol was poured off, DNA pellet was air dried and re-suspended in $200 \mu \mathrm{l}$ of $1 \mathrm{X}$ TE buffer and stored in deep freezer at $-20^{\circ} \mathrm{C}$.

\section{Genotyping}

Genotyping of five isolates of pathogen was carried out using fourteen RAPD markers and eight ISSR markers (Table 2). The PCR amplification was performed according to Williams et al., (1990) with certain modifications and amplicons were separated on 1\%agarose gel. Scoring of bands in each lane was done by comparing with $100 \mathrm{bp}$ ladder of biotechnology grade from Hi-media laboratory. The data was recorded from each line as the bands were scored ( 0 ) for absence and (1) for the presence for the band. A similarity matrix was generated from the binary data using Jaccard's similarity coefficient in the SIMQUAL program of the NTSYS-pc package.

Cluster analysis was performed with the unweighed pair group arithmetic mean method (UPGMA) in the SAHN program of the NTSYS-pc package. The graphic dendrogram of the genetic relatedness among the five isolated was produced by means of UPGMA (Un-weighted Pair Group Method with Arithmetic average) cluster analysis of averaged similarity index.

\section{Results and Discussion}

\section{Isolation of $X$. axonopodis pv. citri}

Creamy or pale yellow colonies of $X$. axonopodis $p v$. citri were observed on NA medium (Fig. 1). Straight and rod shaped bodies containing single, polar flagellum was observed under microscope, which confirmed the purity of the culture.

\section{Pathogenicity by detached leaf method}

The symptoms on leaves started to develop from $10^{\text {th }}$ day as pinpoint spots which eventually turned into water soaked lesions with sunken central spot. Isolate $\mathrm{XacV}$ showed largest water soaked lesions surrounded by yellow hallow zone followed by XacII, XacIII, $\mathrm{XacI}$ and XacIV in contrast with control plate inoculated with sterilized water instead of inoculum (Fig. 2). These symptoms confirm the purity of X.axonopodis pv. citri cultures.

\section{Morphological and biochemical characteristics of $X$. axonopodis pv. citri}

All the isolates were studied with respect to their colony color, shape and Grams staining reaction. Bacterial cells appeared short rod and Gram negative. All five isolates were positive for starch hydrolysis, forming a clear hallow around the colony by hydrolyzing the starch. In $\mathrm{KOH}$ test all the isolates formed thread like slime after addition of $\mathrm{KOH}$. All isolates were catalytically active as they produced bubbles of oxygen within one minute after addition of $\mathrm{H}_{2} \mathrm{O}_{2}$. All five isolates development of cherry red color after addition of Kovac's reagent into culture supernatant confirmed Indole production. Bacteria utilized Dextrose as carbon source and were observed as positive for production of acid and gas. All isolates were observed to start liquification of the gelatin after seven days (Fig. 3; Table 3).

\section{Molecular variability}

\section{RAPD marker}

Out of fourteen randomly selected primers screened seven primers produced reproducible and scorable bands with high degree of polymorphism (Fig. 4). Forty seven amplicons were obtained with the seven primers. All were found to be polymorphic and the level of polymorphism was $100 \%$ (Table 4). 
Table.1 Details of locations of isolate collection

\begin{tabular}{|l|l|l|l|l|l|}
\hline Sl. No & State & District & $\begin{array}{l}\text { Place of } \\
\text { collection }\end{array}$ & Geographic coordinates & Code \\
\hline $\mathbf{1}$ & Maharashtra & Ahmednagar & Vadgavlandga & $19^{\circ} 34^{\prime} \mathrm{N}, 74^{\circ} 5^{\prime} \mathrm{E}$ & XacI \\
\hline $\mathbf{2}$ & Maharashtra & Pune & Pharandwadi & $18^{\circ} 41^{\prime} \mathrm{N}, 73^{\circ} 39^{\prime} \mathrm{E}$ & XacII \\
\hline $\mathbf{3}$ & Maharashtra & Solapur & Pandharpur & $17^{\circ} 40^{\prime} \mathrm{N}, 75^{\circ} 19^{\prime} \mathrm{E}$ & XacIII \\
\hline $\mathbf{4}$ & Maharashtra & Nashik & Muldondri & $19^{\circ} 59^{\prime} \mathrm{N}, 73^{\circ} 47^{\prime} \mathrm{E}$ & XacIV \\
\hline $\mathbf{5}$ & Karnataka & Belgaon & Belgaon & $15^{\circ} 50^{\prime} \mathrm{N}, 74^{\circ} 29^{\prime} \mathrm{E}$ & XacV \\
\hline
\end{tabular}

Table.2 RAPD and ISSRprimers selected for PCR

\begin{tabular}{|c|c|c|c|}
\hline Sr.no & $\begin{array}{l}\text { Marker } \\
\text { type }\end{array}$ & $\begin{array}{l}\text { Primer } \\
\text { screened }\end{array}$ & Sequence $\left(5^{\prime}-3^{\prime}\right)$ \\
\hline 1 & \multirow[t]{14}{*}{ RAPD } & ERIC 1R & ATGTAAGCTCCTGGGGATTCAC \\
\hline 2 & & ERIC 2 & AAGTAAGTGACTGGGGTGAGCG \\
\hline 3 & & a211 & GAACCGCGAT \\
\hline 4 & & a230 & CGTCGCCCAT \\
\hline 5 & & a232 & CGGTGACAT \\
\hline 6 & & REP & CGCGCATCGGC \\
\hline 7 & & OPA 18 & AGGTGACCGT \\
\hline 8 & & OPF 4 & GGTGATCAGG \\
\hline 9 & & OPF6 & GGGAATTCGG \\
\hline 10 & & OPF9 & CCAAGCTTCC \\
\hline 11 & & OPF10 & GGAAGCTTGG \\
\hline 12 & & OPF12 & ACGGTACCAG \\
\hline 13 & & OPB01 & GTTTCGCTCC \\
\hline 14 & & BOX & CTACGGCAAGGCGACGCT \\
\hline 15 & \multirow[t]{8}{*}{ ISSR } & ISSR 820 & GTGTGTGTGTGTGTGTC \\
\hline 16 & & ISSR827 & ACACACACACACACACACACACACACACACACACACG \\
\hline 17 & & ISSR816 & CACACACACACACACAT \\
\hline 18 & & ISSR811 & GAGAGAGAGAGAGAGAC \\
\hline 19 & & ISSR8 & CACACACACACACAGC \\
\hline 20 & & ISSR857(101) & ACACACACACACACYC \\
\hline 21 & & UBC8932800 & AGCAGCAGCAGCGT \\
\hline 22 & & UBC8932814 & CGAGAGAGAGAGAGA \\
\hline
\end{tabular}


Table.3 Morphological and Biochemical characteristics of Xanthomonas axonopodis pv. citri isolates

\begin{tabular}{|c|c|c|c|c|c|c|}
\hline Sr. No. & $\begin{array}{l}\text { Morphological \& } \\
\text { Biochemical Tests }\end{array}$ & XacI & XacII & XacIII & XacIV & $X a c \mathrm{~V}$ \\
\hline 1. & Colony colour & Yellow & Yellow & $\begin{array}{l}\text { Pale } \\
\text { Yellow }\end{array}$ & Yellow & $\begin{array}{l}\text { Dark } \\
\text { yellow }\end{array}$ \\
\hline 2. & Gram's reaction & -ve & -ve & -ve & -ve & -ve \\
\hline 3. & Starch hydrolysis & +++ & +++ & +++ & + & + \\
\hline 4. & Indole production & ++ & + & + & ++ & +++ \\
\hline 5. & Catalase test & +++ & +++ & ++ & +++ & + \\
\hline 6. & $\mathrm{KOH}$ test & +++ & + & ++ & ++ & +++ \\
\hline 7. & Gelatin liquefaction & + & ++ & +++ & + & +++ \\
\hline 8. & Acid production & + & ++ & +++ & ++ & + \\
\hline
\end{tabular}

Table.4 Per cent polymorphism observed in RAPD primers

\begin{tabular}{|c|c|c|c|c|}
\hline Sr. No. & Primer & Total bands & Polymorphic bands & \% Polymorphism \\
\hline $\mathbf{1 .}$ & ERIC2 & 5 & 5 & 100 \\
\hline 2. & REP & 9 & 9 & 100 \\
\hline 3. & BOX & 4 & 4 & 100 \\
\hline $\mathbf{4 .}$ & OPF04 & 6 & 6 & 100 \\
\hline $\mathbf{5 .}$ & OPB01 & 7 & 7 & 100 \\
\hline 6. & OPA18 & 8 & 8 & 100 \\
\hline 7. & a211 & 8 & 8 & 100 \\
\hline
\end{tabular}

Table.5 Binary similarity matrix for RAPD primers

\begin{tabular}{|l|l|l|l|l|l|}
\hline & XacI & XacII & XacIII & XacIV & XacV \\
\hline XacI & 1.0000000 & & & & \\
\hline XacII & 0.1304348 & 1.0000000 & & & \\
\hline XacIII & 0.2727273 & 0.2727273 & 1.0000000 & & \\
\hline XacIV & 0.1481481 & 0.3823529 & 0.2250000 & 1.0000000 & \\
\hline XacV & 0.1363636 & 0.3793103 & 0.4000000 & 0.3055556 & 1.0000000 \\
\hline
\end{tabular}

Table.6 Per cent polymorphism observed in ISSR primers

\begin{tabular}{|c|c|c|c|c|}
\hline Sr. No. & Primer & $\begin{array}{l}\text { Total } \\
\text { bands }\end{array}$ & $\begin{array}{l}\text { Polymorphic } \\
\text { bands }\end{array}$ & \% Polymorphism \\
\hline 1 & ISSR820 & 11 & 11 & 100 \\
\hline 2 & UBC8932800 & 02 & 02 & 100 \\
\hline 3 & ISSR816 & 06 & 06 & 100 \\
\hline
\end{tabular}


Int.J.Curr.Microbiol.App.Sci (2018) 7(8): 2375-2384

Table.7 Binary similarity matrix for ISSR primers

\begin{tabular}{|l|l|l|l|l|l|}
\hline & XacI & XacII & Xac III & XacIV & XacV \\
\hline XacI & 1.0000000 & & & & \\
\hline XacII & 0.0000000 & 1.0000000 & & & \\
\hline XacIII & 0.1666667 & 0.5000000 & 1.0000000 & & \\
\hline XacIV & 0.3333333 & 0.5000000 & 0.2727273 & 1.0000000 & \\
\hline Xac V & 0.1818182 & 1.0000000 & 0.5833333 & 0.1818182 & 1.0000000 \\
\hline
\end{tabular}

Fig.1 Pale yellow colonies of $X$. axonopodis pv. citri

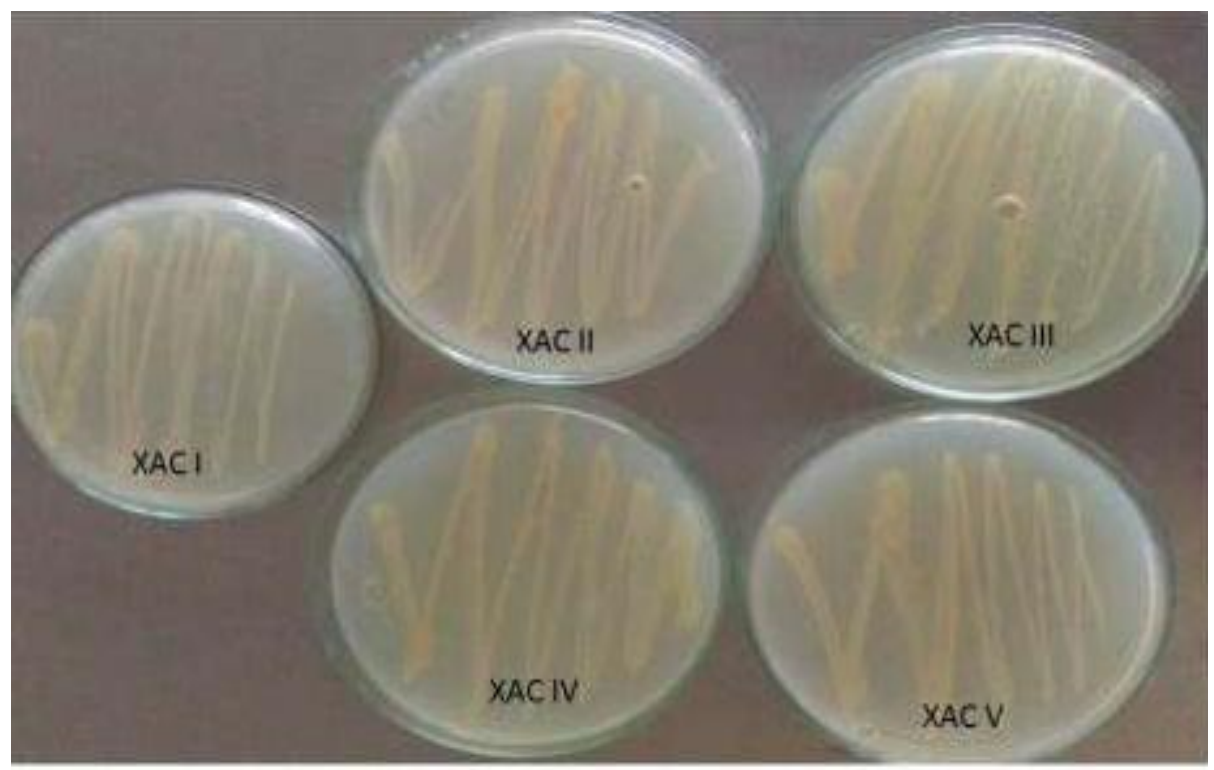

Fig.2 The symptoms of Citrus canker on leaves

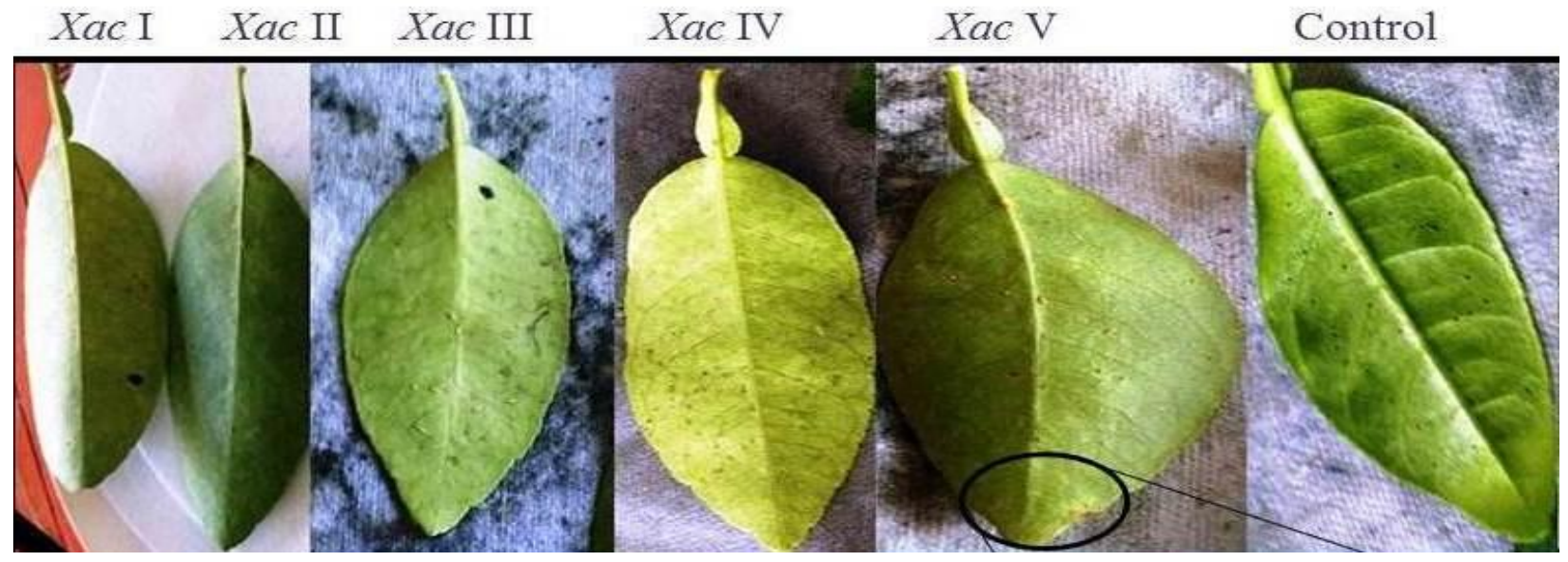


Fig.3 Morphological and Biochemical characteristics of Xanthomonas axonopodis pv. citri isolates (a) Gram test, (b) Catalase test, (c) Acid production test, (d) Indol production test, (e) $\mathrm{KOH}$ test, (f) Starch hydrolysis test, (g) Gelatin liquefaction test

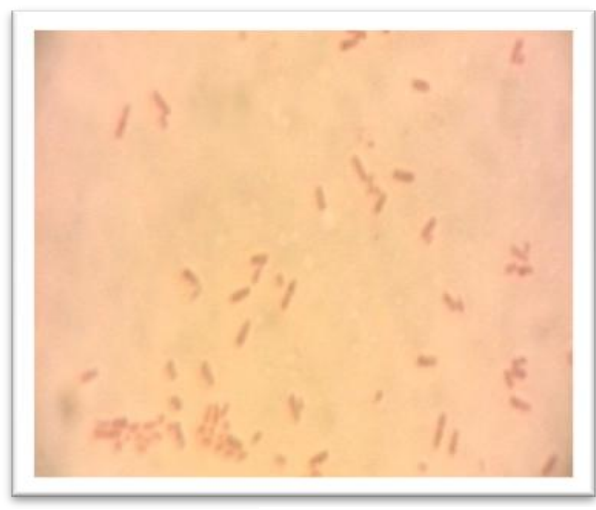

(a)

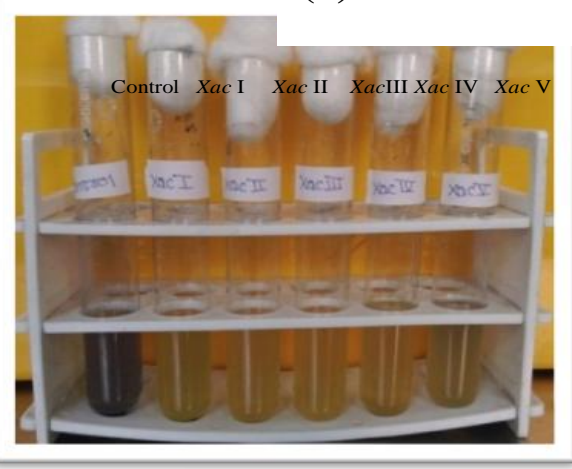

(c)

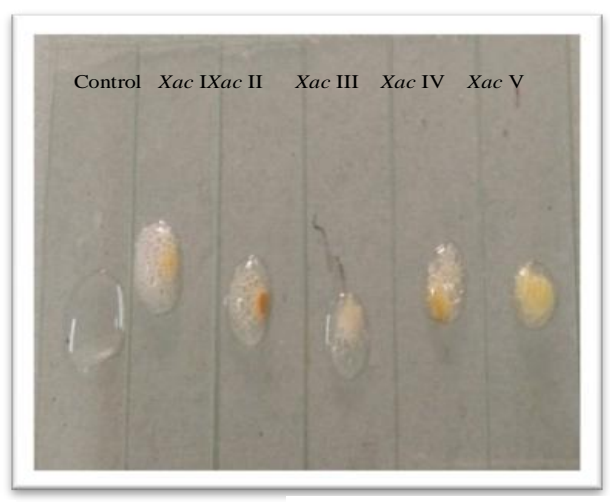

(b)

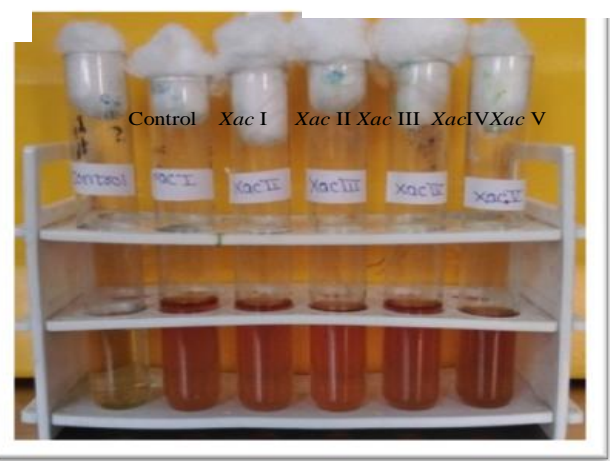

(d)

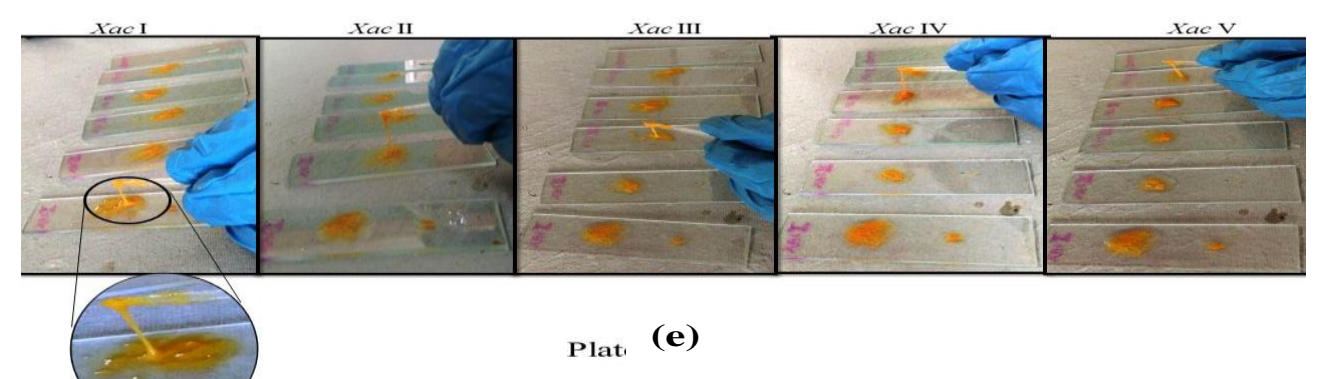

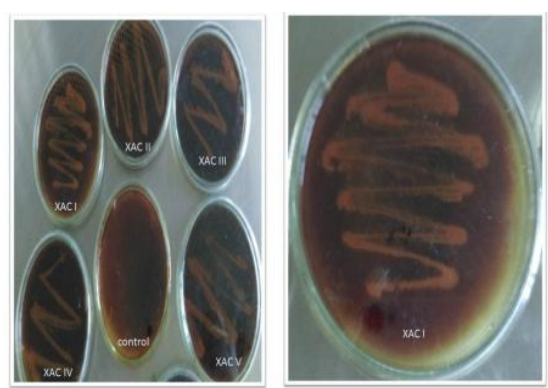

(f)

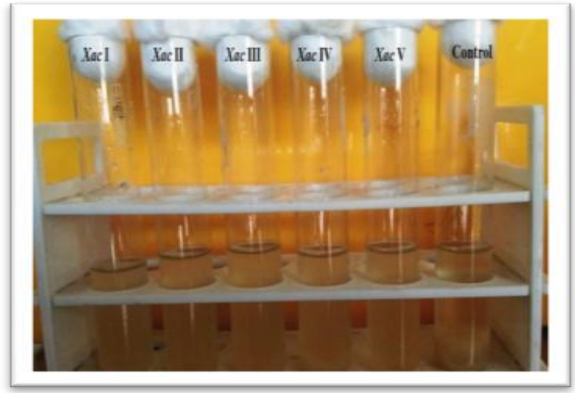

(g) 
Fig.4 Banding pattern of (a) RAPD and (b) ISSR primers
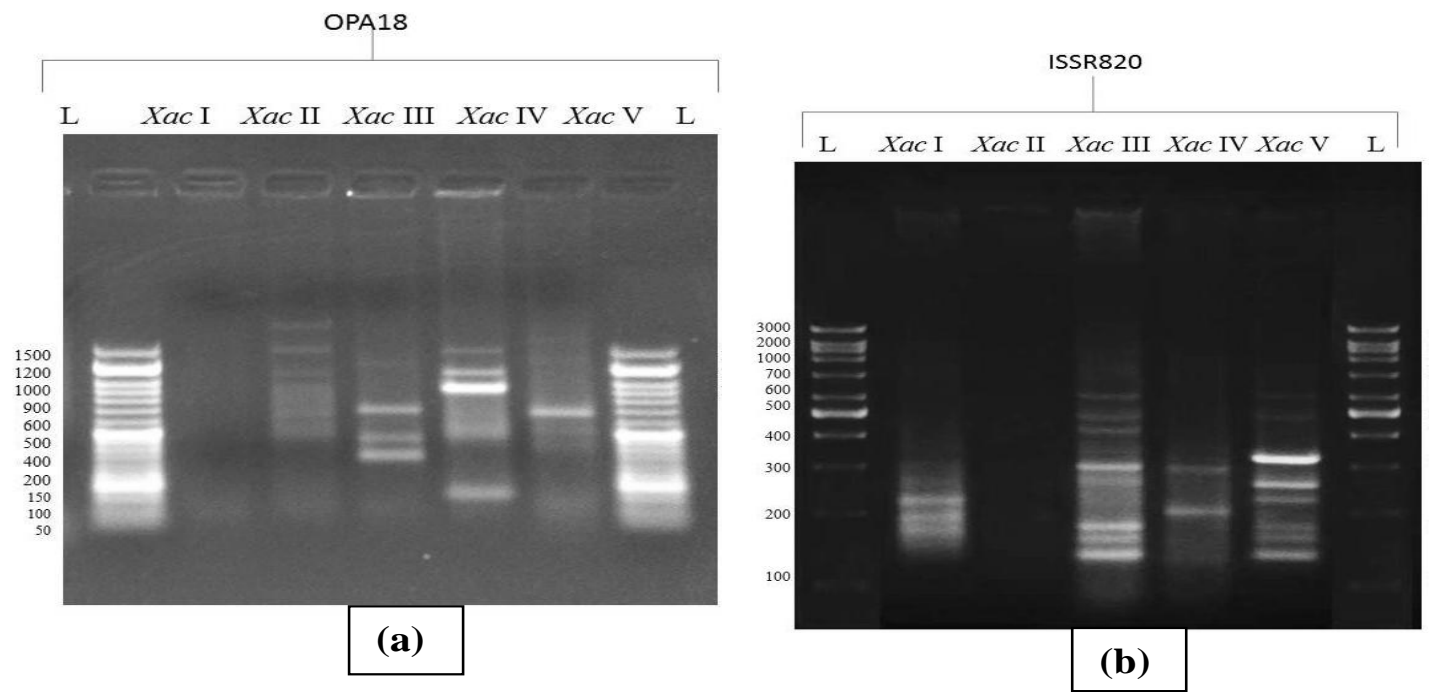

Fig.5 The UPGMA dendrogram of five isolates of $X$. axonopodis pv. citri based on Jaccard's similarity coefficient (a) RAPD (b) ISSR

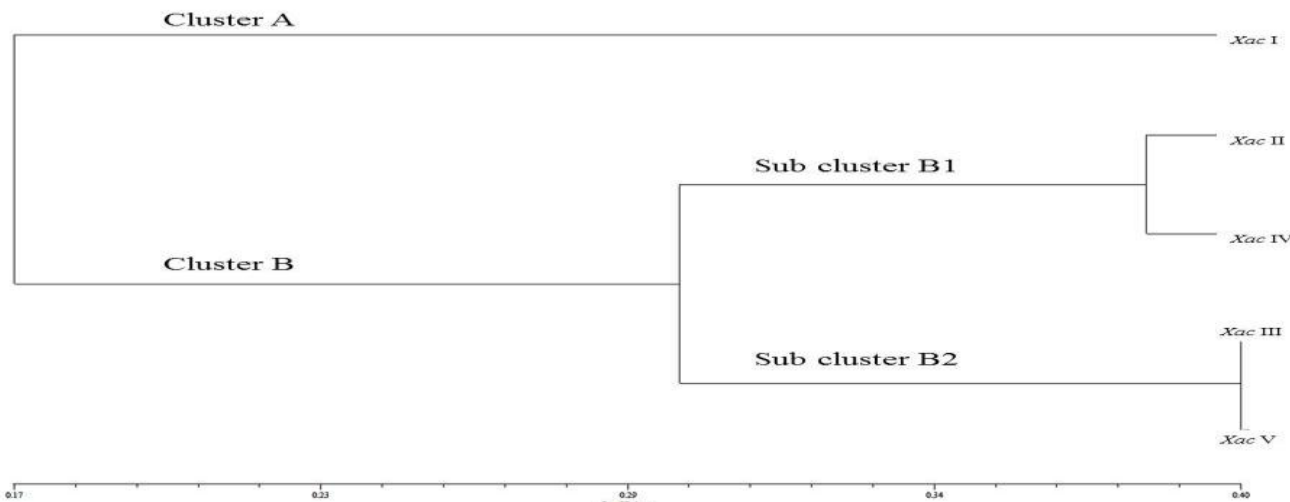

(a)

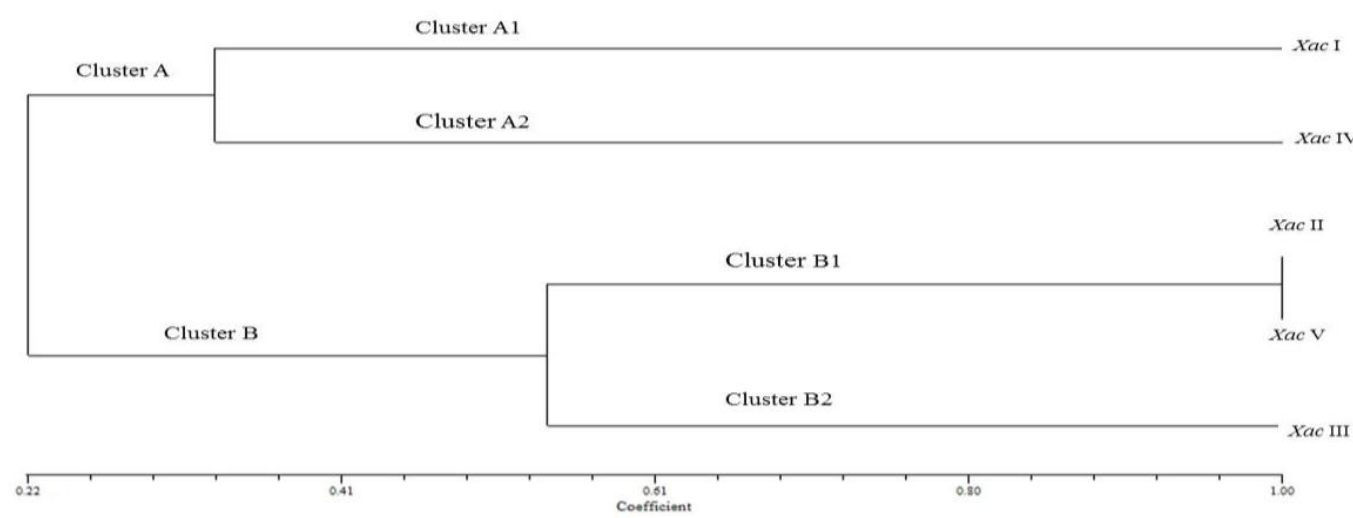

(b) 
The similarity coefficient value ranged from 0.13 to 0.40 across five isolates indicating high degree of genetic variation (Table 5).

Isolate $\mathrm{XacI}$ was found to be highly different from XacII (0.1304) followed by all other isolates viz., $X a c \mathrm{~V}, X a c \mathrm{IV}$ and XacIII with similarity coefficient of $0.1364,0.1481$ and 0.2727 respectively. The highest genetic similarity coefficient to an extent of 0.40 was recorded between $X a c \mathrm{III}$ and $\mathrm{XacV}$ isolates followed by 0.38 between XacII and XacIV isolates. The dendrogram constructed by UPGMA for RAPD analysis shows that isolates can be grouped into two major clusters A and B (Fig. 5). Cluster B divided into two sub clusters namely cluster B1 and cluster B2.The cluster A is containing single isolate XacI. Sub cluster B1 shows two isolates $\mathrm{XacII}$ and $\mathrm{XacIV}$, whereas sub cluster B2having two isolate $\mathrm{XacIII}$ and $\mathrm{XacV}$.

\section{ISSR marker}

Out of eight randomly selected markers, two produced reproducible and scorable bands with high degree of polymorphism (Fig. 4). A total thirteen amplicons were obtained with the two primers which were found to be polymorphic and the level of polymorphism was $100 \%$ (Table 6).

The similarity coefficient value ranged from 0.0000 to 1.00 across five isolates (Table 7). Isolate $\mathrm{XacI}$ was found to be highly different from XacII (0.0000) followed by all other isolates viz., XacIII, XacV and XacIV with similarity coefficient of $0.1667,0.1818$ and 0.3333 respectively. The dendrogram grouped the isolates into two major clusters $\mathrm{A}$ and $\mathrm{B}$ (Fig. 5). Cluster A divided into two sub clusters namely cluster A1 and cluster A2. Sub cluster A1 shows isolate XacI and sub cluster A2 shows isolates XacIV. Sub cluster B1 shows two isolates $X a c I I$ and $X a c V$ and sub cluster B2 shows isolates XacIII.

\section{References}

Chaudhry, N. A., Khan, A. R., Hameedullah, 1992. Introduction of acclimatized exotic citrus. Citrus fruit varieties at Horticultural Research Station, Sahiwal. Proc. 1st Int. Sem. Citri culture in Pakistan. University of Agriculture Faisalabad-Pakistan.p: 15.

Cooksey, D. A. and Graham, J. H., 1989.Genomic fingerprinting of two pathovars of phytopathogenic bacteria by rare-cutting restriction enzymes and field inversion electrophoresis. Phytopathol. 79:745-750.

Di, M. U. Y., Schaad, N. W. and Roth, D. A., 1991.Selective recovery of Xanthomonas sp., from rice seed. Phytopathol. 81:1358-1363.

Egel, D. S., Graham, J. H. and Stall, R. E., 1991. Genomic relatedness of Xanthomonas campestris strains causing disease of citrus. Appl. Environ. Microbiol. 57:2724-2730.

FAO (Food and Agriculture Organization), 2017.http//www.fao.org.

Gotwald, T. R., Graham, J. H., Civerolo, E. L., Barrett, H. C., Hearn, C. J., 1993. Differential host range reaction of citrus bacterial spot determined by leaf mesophil susceptibility. Plant Dis. 77:1004- 1009.

Hauben, L., Vauterin, L., Swings, J. and Moore, E. R. B., 1997. Comparison of $16 \mathrm{~S}$ ribosomal DNA sequences of all Xanthomonas species. Int. J. Syst. Bacteriol. 47:328-335.

Khan, M. M., Khan M. A., Inam-ul-Haq M., Ahmad R., Aziz I., 1992. Incidence of citrus canker caused by $X$. campestris pv. citri orchard in Faisalabad District.In: Proceed. 1st Inter. sem. citri culture in Pakistan. University of Agriculture Faisalabad. pp. 311-314.

Kolliker, R., Kraehenbuehl, R., Boller, B., Widmer, F., 2006. Genetic diversity and 
pathogenicity of the grass pathogen Xanthomonas translucens pv. graminis. Syst. Appl. Microbiol. 29:109-119.

Pooler, M. R., Ritchie, D. F. and Hartung, J. S., 1996.Genetic relationships among strains of Xanthomonas fragariae based on random amplified polymorphic DNA PCR, repetitive extragenic palindromic PCR, and enterobacterial repetitive intergenic consensus PCR data and generation of multiplexed PCR primers useful for the identification of this phytopathogen. App. Environ. Microbiol. 62:3121-3127.

Rademaker, J. L., Hoste, B., Louws, F. J., Kersters, K., Swings, J., Vauterin, L., Vauterin, P., Bruijn, F. J., 2000. Comparison of AFLP and rep- PCR genomic fingerprinting with DNA-
DNA homology studies: Xanthomonas as a model system. Int. J. Syst. Evol. Microbiol. 2:665-677.

Schoulties, C. L., Civerolo, E. L., Miller, J. W., Stall, R. E., Krass, C., Poe, S. R., Ducharme, E. P., 1987. Citrus canker in Florida. Plant Dis. 71:388-395.

Simoes, T. H., Goncalves, E. R., Rosato, Y. B., Mehta, A., 2007. Differentiation of Xanthomonas species by PCR-RFLP of rpfB and atpD genes. FEMS Microbiol. Lett. 271:33-39

Williams, J. G. K., Kubelik, A. R., Livak, K. J., Rafalski, J. A., Tingey, S. V., 1990. DNA polymorphisms amplified by arbitrary primers are useful as genetic markers. Nucleic Acids Res. 18:65316535.

\section{How to cite this article:}

Rutuja R. Kharde, Shivaji A. Lavale and Bhausaheb Baban Ghorpade. 2018. Molecular Diversity among the Isolates of Xanthomonas axonopodis pv. citri Causing Bacterial Canker in Citrus. Int.J.Curr.Microbiol.App.Sci. 7(08): 2375-2384.

doi: https://doi.org/10.20546/ijcmas.2018.708.239 